\author{
Robert SZMYTKIE \\ Dr, Zakład Geografii Społeczno-Ekonomicznej, Instytut Geografii i Rozwoju Regionalnego, Uniwersytet Wrocławski \\ robert.szmytkie@uwr.edu.pl
}

Robert KRZYSZTOFIK

Dr hab., Katedra Geografii Ekonomicznej, Uniwersytet Śląski robert_krzysztofik@interia.pl

\title{
POWSTAWANIE MIAST W „STREFACH BEZMIEJSKICH”
}

\begin{abstract}
Abstrakt: Celem artykułu było wyjaśnienie zasadniczych modeli organizacji procesu umiastowienia „stref bezmiejskich” w Polsce, w kontekście oddziałujących miastotwórczych sił dośrodkowych i odśrodkowych oraz towarzyszącemu im zjawisku dyfuzji idei uprawomocnionej miejskości. Ostatecznie wskazano na dwa podstawowe modele umiastowienia w „strefach bezmiejskich” o podłożu mechanicystycznym (siły miastotwórcze) i trzy modele o zdecydowanej roli atrybutu termodynamicznego (dyfuzja).

Słowa kluczowe: „strefy bezmiejskie”, nowe miasta, modele procesów umiastowienia, siły dośrodkowe i odśrodkowe, Polska.
\end{abstract}

\section{DEVELOPMENT OF TOWNS IN ‘NON-URBAN’ ZONES}

Abstract: The purpose of this article was to clarify fundamental models for organizing urbanization process inside of 'non-urban zones' in Poland. This question is analyzed in the context of both urban-forming forces, the centripetal and centrifugal ones, and the phenomenon of the urbanity idea diffusion. Two basic models of urbanization in 'non-urban' zones has been underlined. The first one was based on mechanistic attributes, while the second one on the strong role of thermodynamic attributes (diffusion).

Keywords: 'non-urban' zones, new towns, urbanization, centripetal and centrifugal forces, Poland.

\section{WPROWADZENIE}

Proces umiastowienia jest formalnoprawną konsekwencją wcześniejszej urbanizacji. W Polsce trwa on nieprzerwanie od początków XIII w. Znacząco zaznaczył się także w ostatnim 40-leciu. Jakkolwiek w odniesieniu do przeszłości zmieniła się współcześnie skala oraz niektóre formy organizacji czynników miastotwórczych, to stałe pozostają siły, które stanowią wobec tych czynników nadrzędny poziom wyjaśniania procesów urbanizacji i umiastowienia. Siły te, które $\mathrm{w}$ artykule zawężamy do pojęcia miastotwórczych sił dośrodkowych i odśrodkowych, mają kluczowe znaczenie $\mathrm{w}$ powstawaniu miast $\mathrm{i}$ ich dalszym rozwoju. Ich oddziaływaniu towarzyszy w przestrzeni społeczno-ekonomicznej proces dyfuzji. W rozpatrywanej tu problematyce chodzi konkretnie o dyfuzję innowacji, jaką jest idea miejskości rozpatrywana $\mathrm{z}$ formalnoprawnego punktu widzenia. Przyjmujemy w artykule zatem ujęcie mechanicystyczno-termodynamiczne wyjaśniania modeli współczesnego umiastowienia teryto- rium Polski. Modele te odniesione zostały do okresu 1978-2016, a badaniami objęto całe terytorium Polski.

Celem autorów artykułu było zatem wyjaśnienie zasadniczych modeli organizacji procesu umiastowienia „stref bezmiejskich” w Polsce, w kontekście działania miastotwórczych sił dośrodkowych i odśrodkowych oraz towarzyszącej im dyfuzji idei uprawomocnionej miejskości. Ostatecznie wskazano na dwa podstawowe modele umiastowienia $\mathrm{w}$,strefach bezmiejskich" o podłożu mechanicystycznym (siły miastotwórcze) i trzy modele o zdecydowanej roli atrybutu termodynamicznego (dyfuzja). W pracy uwzględniono pojęcia umiastowienia i urbanizacji, skupiając uwagę na tym pierwszym. Ma ono w przekonaniu autorów węższe znaczenie i odnosi się do zjawiska powstawania miast de iure, podczas gdy urbanizacja jest pojęciem szerszym, definiującym część zjawisk społeczno-ekonomicznych mających miejsce także na obszarach formalnie wiejskich (Krzysztofik 2012). 


\section{ZMIANY LICZBY MIAST W LATACH 1978-2016}

W 1977 r. zakończył się proces dostosowywania jednostek podziału terytorialnego do nowych realiów podziału administracyjnego, co było konsekwencją reformy administracyjnej z 1975 r., która wprowadziła dwustopniowy podział administracyjny i znacząco zwiększyła liczbę województw (Ustawa o dwustopniowym podziale administracyjnym Państwa oraz o zmianie ustawy o radach narodowych z 28 maja 1975 r.), oraz wcześniejszej reformy (z 1973 r.), w wyniku której $\mathrm{w}$ miejsce gromad przywrócone zostały gminy i zniesiono kategorię osiedla miejskiego (Ustawa o utworzeniu gmin $i$ zmianie ustawy o radach narodowych z 29 listopada 1972 r.). Rok 1977 był także przełomowy $\mathrm{w}$ zakresie ustabilizowania procesów inkorporacji miast mniejszych do większych, które w kolejnych latach występowały jedynie incydentalnie (w 2002 r. w granice Warszawy wcielone zostało miasto Wesoła). Ponadto po 1973 r. żadne polskie miasto nie zostało zdegradowane do kategorii wsi (jako ostatnie tego statusu doświadczyły: Lędyczek, Miasteczko Krajeńskie, i na okres kilku miesięcy, Sulmierzyce) (Sokołowski 2008, Dymitrow 2012, Szmytkie 2012). Zapoczątkowało to okres stopniowego wzrostu liczby miast w Polsce, z 803 w 1978 r. do 919 w 2016 r. (rys. 1). Prawa miejskie w analizowanym okresie otrzymało zatem 117 miejscowości.

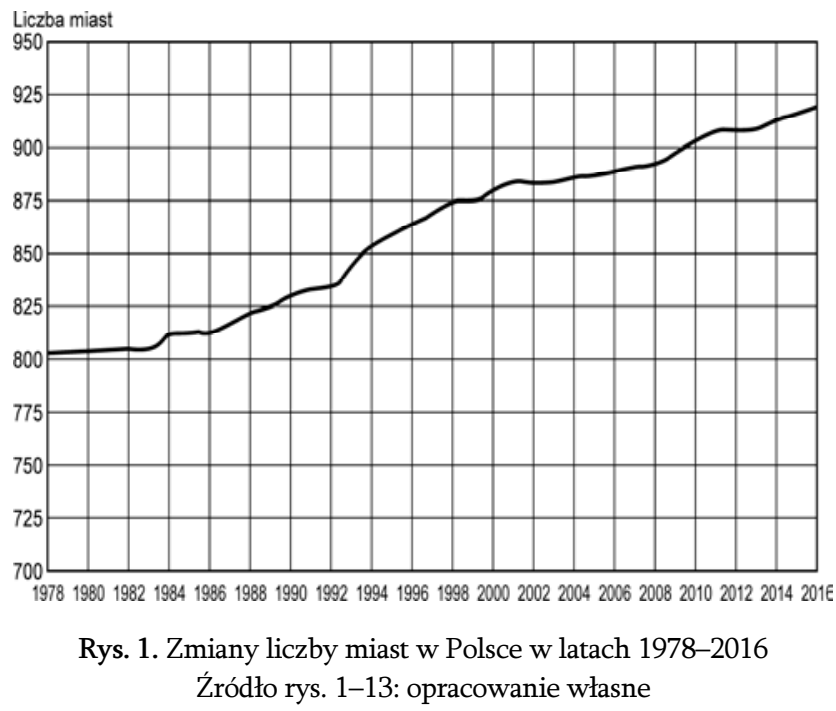

Z uwagi na przeszłość historyczną zbiór nowych miast można podzielić na cztery grupy (por. Drobek 1999, 2002, Krzysztofik 2006, Szmytkie, Krzysztofik 2011, Lisowska, Szmytkie 2014):
1) miejscowości posiadające $\mathrm{w}$ przeszłości prawa miejskie (miasta zdegradowane), dla których nadanie praw miejskich miało charakter restytucji miejskości;

2) dawne osiedla miejskie (czyli miejscowości posiadające status osiedla w latach 1954-1973);

3) miejscowości, które otrzymały prawa miejskie $\mathrm{w}$ wyniku secesji (tzn. usamodzielnienia się po okresie funkcjonowania jako część innego miasta);

4) zupełnie nowe miasta (czyli miejscowości bez tradycji miejskich).

W grupie miast ustanowionych w latach 1978-2016 przeważają ośrodki, które otrzymały prawa miejskie na zasadzie restytucji (81, czyli 69,2\% ogółu nowych miast) (rys. 2). W większości są to jednostki o długich (zwykle kilkuwiekowych) tradycjach miejskich, które status miasta utraciły $\mathrm{w}$ drugiej połowie XIX w. lub w pierwszej połowie XX w. (Krzysztofik 2007, Najgrakowski 2009). Miejską przeszłość mają także miejscowości, które odzyskały samodzielność administracyjną (i miejski status) po okresie funkcjonowania jako część innego miasta (Szmytkie 2005) oraz w pewnym sensie (Szmytkie 2003) dawne osiedla miejskie (w sumie 16 nowych miast). W analizowanym okresie powstało również 20 zupełnie nowych miast (17,1\%), które nigdy nie posiadały praw miejskich.

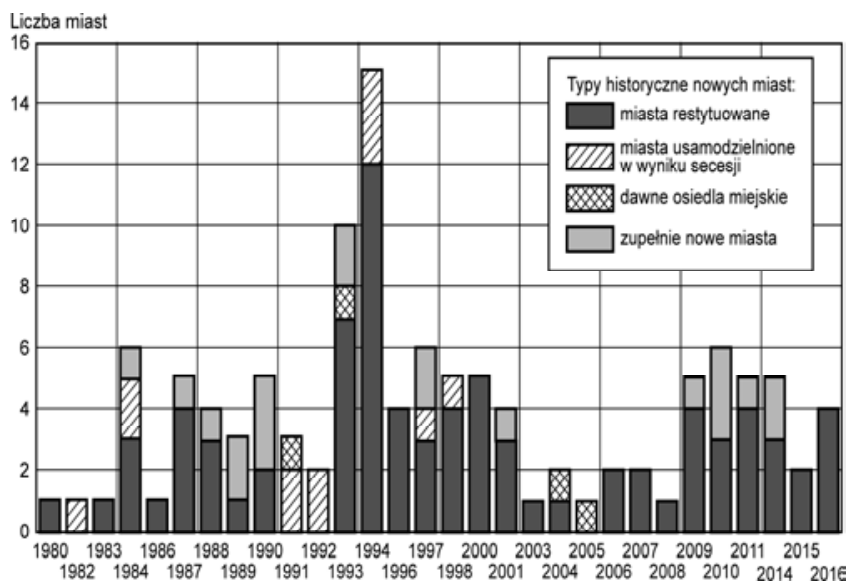

Rys. 2. Przeszłość historyczna miast ustanowionych w latach 1978-2016

Typy historyczne nowych miast: R) miasta restytuowane, S) miasta usamodzielnione w wyniku secesji, O) dawne osiedla miejskie, N) zupełnie nowe miasta

Średnia liczba ludności w momencie otrzymania praw miejskich $\mathrm{w}$ przypadku miast ustanowionych w latach 1978-2016 wyniosła około 4 tys. osób. Nowe miasta charakteryzują się jednak zróżnicowaną liczbą 
mieszkańców (rys. 3), przy czym przeważają wśród nich miasta liczące od 2 do 6 tys. mieszkańców (Powierzchnia... 1994-2015). W roku uzyskania praw miejskich największą liczbę ludności miało miasto Rydułtowy (23 900 mieszkańców w 1992 r.), a najmniejszą Borne Sulinowo (134 mieszkańców w 1993 r.). Warto jednak zauważyć, że poszczególne typy historyczne nowych miast cechują się zróżnicowaną średnią liczbą ludności. W przypadku jednostek powstałych z miast zdegradowanych i dawnych osiedli miejskich wynosiła ona odpowiednio 2699 i 2892 osoby, zupełnie nowe liczyły średnio 3927 mieszkańców, a miasta przywrócone w wyniku secesji aż $13309^{1}$.

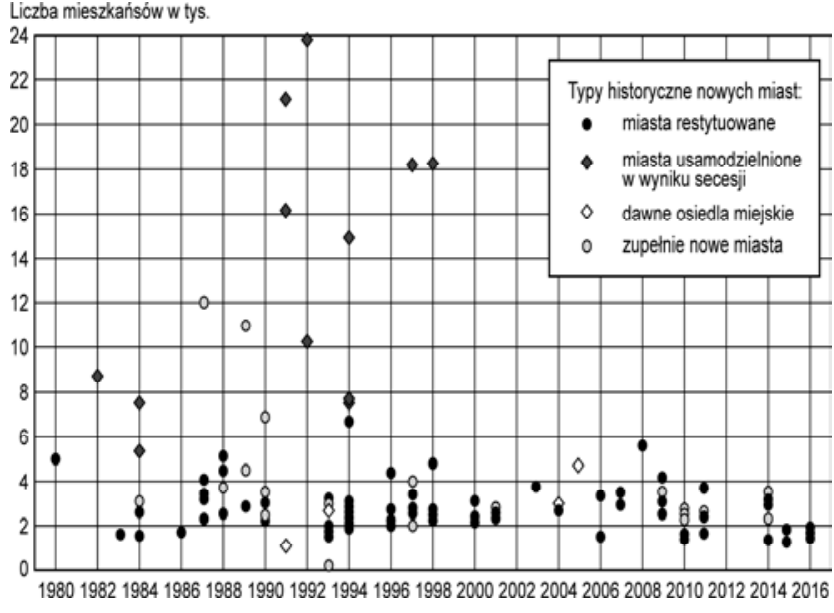

Rys. 3. Liczba ludności nowych miast w roku nadania im praw miejskich

Źródło: opracowanie własne na podstawie: Powierzchnia... (2016)

Tab. 1. Strefy dyfuzji idei umiastowienia w Polsce

\begin{tabular}{|c|c|c|c|c|c|c|}
\hline \multirow{2}{*}{ Nazwa strefy } & \multirow{2}{*}{$\begin{array}{c}\text { Liczba } \\
\text { nowych } \\
\text { miast }\end{array}$} & \multicolumn{3}{|c|}{ Typy nowych miast } & \multirow{2}{*}{ Etap dyfuzji } & \multirow{2}{*}{ Nowe miasta } \\
\hline & & $\mathrm{R}$ & $\mathrm{O}$ & $\mathrm{N}$ & & \\
\hline Płocka & 4 & 3 & - & 1 & ekspansji & Glinojeck, Bieżuń, Drobin, Skępe \\
\hline Podlaska & 9 & 7 & - & 2 & konsolidacji & $\begin{array}{l}\text { Lipsk, Kleszczele, Tykocin, Suchowola, Kosów Lacki, } \\
\text { Krynki, Michałowo, Szepietowo, Czyżew }\end{array}$ \\
\hline Świętokrzyska & 13 & 12 & - & 1 & nasycenia $^{\text {a) }}$ & $\begin{array}{l}\text { Połaniec, Ożarów, Kunów, Sędziszów, Bodzentyn, } \\
\text { Osiek, Wąchock, Annopol, Małogoszcz, Koprzywnica, } \\
\text { Daleszyce, Zaklików, Stopnica }\end{array}$ \\
\hline Tarnowska & 13 & 12 & - & 1 & nasycenia ${ }^{b)}$ & $\begin{array}{l}\text { Nowy Wiśnicz, Ciężkowice, Czchów, Ryglice, } \\
\text { Zakliczyn, Wojnicz, Bobowa, Szczucin, Brzostek, } \\
\text { Radłów, Kołaczyce, Przecław, Nowe Brzesko }\end{array}$ \\
\hline Warmińska & 7 & 6 & 1 & - & konsolidacji & $\begin{array}{l}\text { Młynary, Kisielice, Zalewo, Krynica Morska, Pasym, } \\
\text { Miłakowo, Miłomłyn }\end{array}$ \\
\hline Wielkopolska & 4 & 4 & - & - & ekspansji & Nekla, Dobrzyca, Chocz, Jaraczewo \\
\hline Zamojska & 13 & 12 & - & 1 & nasyceniac) & $\begin{array}{l}\text { Tarnogród, Józefów, Oleszyce, Zwierzyniec, Frampol, } \\
\text { Krasnobród, Narol, Tyszowce, Łaszczów, Modlibo- } \\
\text { rzyce, Lubycza Królewska, Siedliszcze, Urzędów }\end{array}$ \\
\hline
\end{tabular}

Objaśnienia: typy historyczne nowych miast: $\mathrm{R}$ - miasta restytuowane, $\mathrm{O}$ - dawne osiedla miejskie, $\mathrm{N}$ - zupełnie nowe miasta.

a) Proces umiastowienia w przypadku tej strefy przekroczył barierę Wisły i zaczyna obejmować północną część województwa podkarpackiego. b) Proces umiastowienia w przypadku tej strefy przerzucił się do zachodniej części województwa podkarpackiego (powiaty dębicki, jasielski, mielecki). c) Proces umiastowienia w przypadku tej strefy przerzucił się do środkowej części województwa lubelskiego.

Źródło: opracowanie własne, etapy dyfuzji na podstawie: J. Łoboda (1983).

Tab. 2. Dyfuzyjne układy zalążkowe w Polsce

\begin{tabular}{|l|c|c|c|c|l|}
\hline \multirow{2}{*}{ Nazwa strefy } & \multirow{2}{*}{$\begin{array}{c}\text { Liczba } \\
\text { nowych } \\
\text { miast }\end{array}$} & \multicolumn{3}{|c|}{ Typy nowych miast } & \multirow{2}{*}{ Nowe miasta } \\
\cline { 3 - 5 } & 2 & $\mathrm{R}$ & $\mathrm{O}$ & $\mathrm{N}$ & \\
\hline Lubuska & 2 & 1 & - & - & Torzym, Lubniewice \\
\hline Sudecka & 2 & 2 & - & - & Świerzawa, Olszyna \\
\hline Opolska & 2 & 3 & - & - & Korfantów, Prószków \\
\hline Piotrkowska & 3 & - & 1 & 2 & Golczewzyn, Kamieńsk, Wolbórz \\
\hline Zachodniwón, Stepnica \\
\hline Podkarpacka & 3 & 2 & - & - & Boguchwała, Pruchnik \\
\hline
\end{tabular}

Źródło: opracowanie własne. 


\section{MODELE PROCESÓW UMIASTOWIENIA}

Umiastowienie jest konsekwencją procesu urbanizacji danej miejscowości. Dynamikę tego procesu w lokalnej sieci osadniczej można usystematyzować $\mathrm{w}$ ramach czterech podstawowych modeli skupiania nowych miast (por. Krzysztofik 2006). Analizując rozmieszczenie miast ustanowionych $\mathrm{w}$ Polsce $\mathrm{w}$ latach 1980-2016 można stwierdzić, że szczególną rolę $\mathrm{w}$ procesie wzrostu liczby miast $\mathrm{w}$ tym okresie odegrały następujące modele: w tym okresie), przy czym niewielki udział w tej grupie $(9,5 \%)$ stanowiły miasta zupełnie nowe (czyli uzyskujące prawa miejskie po raz pierwszy). Poszczególne strefy charakteryzują się ponadto różnym poziomem zaawansowania procesów dyfuzji (rys. 4).

Na terenie Polski wyróżniono także jedną strefę dyfuzji idei usamodzielnienia - strefę katowicką w województwie śląskim. W jej obrębie w wyniku procesów secesji (zwykle po krótkim okresie funkcjonowania jako części innych miast), zachodzących głównie w latach 90. XX w., samodzielność administracyjną odzyskało 11 miast i 21 miejscowości wiejskich (rys. 5) (Powierzchnia... 1994-2015, Jarczewski 2002, Szmytkie 2005, 2014).

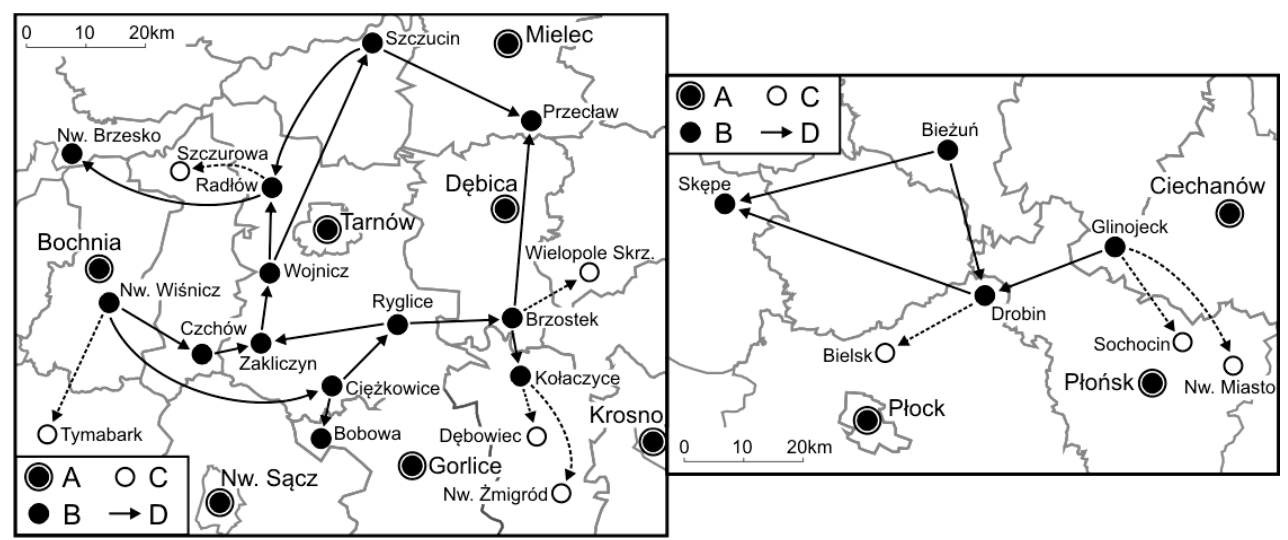

Rys. 4. Wybrane strefy dyfuzji idei umiastowienia w Polsce (strefa tarnowska i strefa płocka) $\mathrm{A}$ - wybrane miasta powiatowe, $\mathrm{B}$ - nowe miasta, $\mathrm{C}$ - potencjalne nowe miasta $\mathrm{D}$ - kierunki dyfuzji idei umiastowienia

1) powstawanie nowych miast jako wynik dyfuzji idei miejskości (umiastowienia),

2) powstawanie nowych miast jako wynik dyfuzji idei usamodzielnienia,

3) powstawanie nowych miast w strefie ekspansji aglomeracji miejskich,

4) powstawanie i dyfuzja nowych miast $w$ „strefach bezmiejskich".

Rozprzestrzenianie się ośrodków uzyskujących prawa miejskie (lub samodzielność administracyjną) ze względu na charakter i przebieg tego procesu, można traktować jako zjawisko dyfuzji innowacji (Łoboda 1983), a mechanizm tych procesów ma wyraźne uwarunkowania społeczno-ekonomiczne (Krzysztofik 2006). Na terenie Polski można wyróżnić siedem stref dyfuzji idei umiastowienia (tab. 1) oraz sześć tzw. dyfuzyjnych układów zalążkowych (tab. 2)². W latach 1978-2016 $\mathrm{w}$ strefach dyfuzji idei umiastowienia ustanowione zostały w sumie 63 miasta $(53,8 \%$ miast powołanych

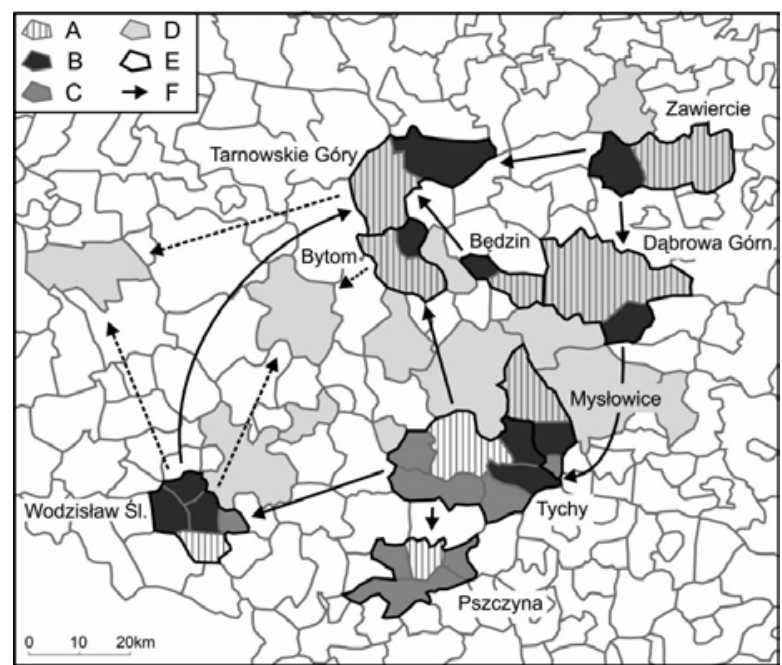

Rys. 5. Katowicka strefa dyfuzji idei usamodzielnienia A - miasta, które straciły część swojego terytorium w wyniku secesji, B - miasta usamodzielnione w wyniku secesji, C - miejscowości wiejskie usamodzielnione w wyniku secesji, D - miasta zawierające w swych granicach inne miasta, E - granice miast przed secesją, F - kierunki dyfuzji idei usamodzielnienia 
Tab. 3. Strefy aglomeracyjne rozwoju nowych miast w Polsce

\begin{tabular}{|l|c|c|c|l|}
\hline \multirow{2}{*}{ Nazwa strefy } & \multirow{2}{*}{$\begin{array}{c}\text { Liczba } \\
\text { nowych } \\
\end{array}$} & \multicolumn{2}{|c|}{ Typy nowych miast } & \multirow{2}{*}{ Nowe miasta } \\
\cline { 3 - 5 } & miast & $\mathrm{R}$ & $\mathrm{N}$ & \\
\hline Aglomeracja warszawska & 3 & 1 & 2 & Łomianki, Halinów, Tarczyn \\
\hline Konurbacja katowicka & 4 & 4 & - & Alwernia, Pilica, Sośnicowice, Krzanowice \\
\hline Aglomeracja krakowska & 2 & 1 & 1 & Skała, Świątniki Górne \\
\hline Aglomeracja łódzka & 1 & 1 & - & Rzgów \\
\hline Aglomeracja wrocławska & 3 & 1 & 2 & Jelcz-Laskowice, Siechnice, Prusice \\
\hline Aglomeracja poznańska & 1 & 1 & - & Obrzycko \\
\hline Aglomeracja trójmiejska & 1 & - & 1 & Żukowo \\
\hline
\end{tabular}

Objaśnienia: typy historyczne nowych miast: $\mathrm{R}$ - miasta restytuowane, $\mathrm{O}$ - dawne osiedla miejskie, $\mathrm{N}$ - zupełnie nowe miasta.

Źródło: opracowanie własne.

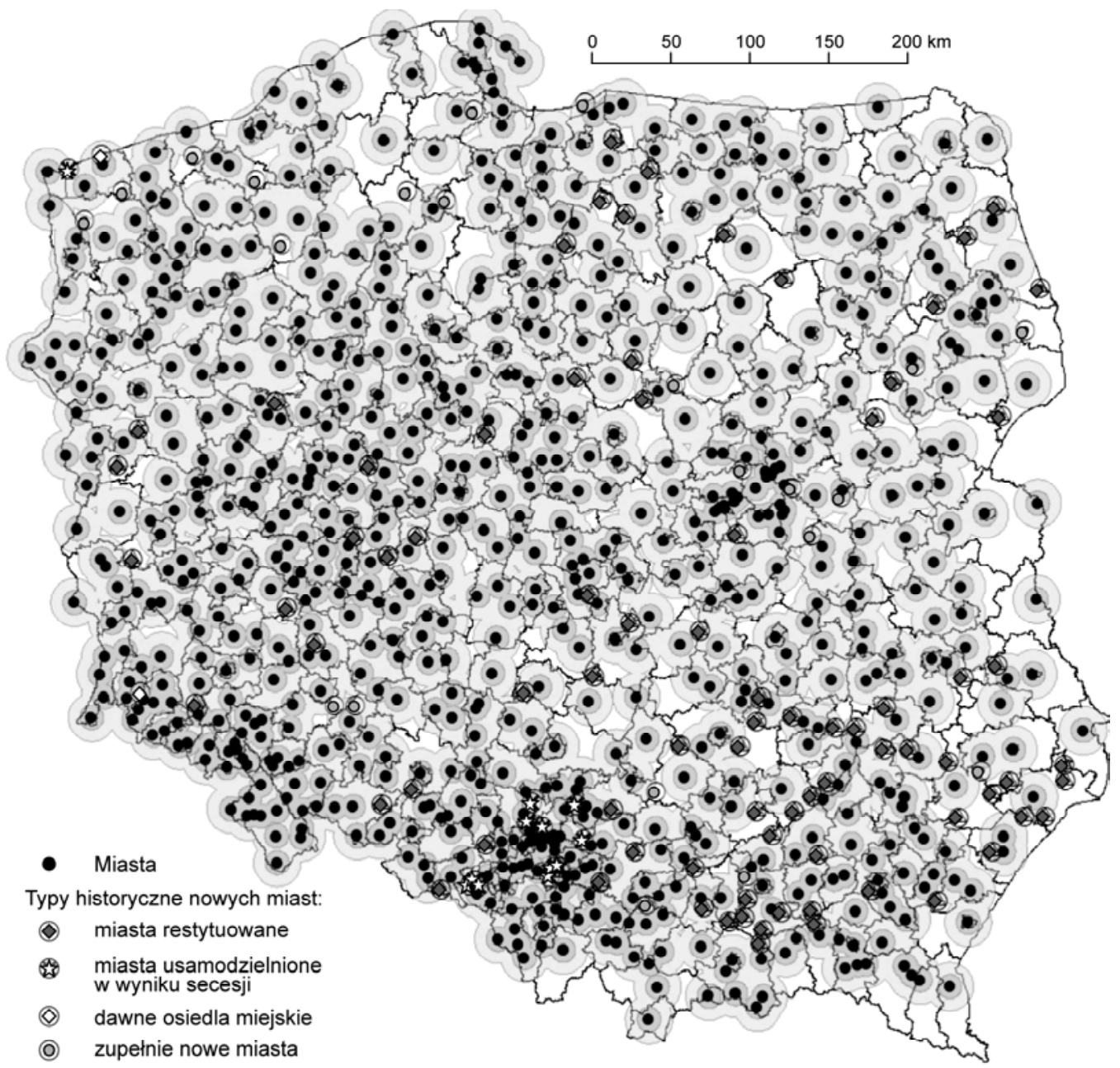

Rys. 6. Miasta ustanowione w latach 1980-2016 na tle stref buforowych (o promieniach 1 i 2 mili) wokół miast istniejących w $1978 \mathrm{r}$.

Typy historyczne nowych miast: R) miasta restytuowane, S) miasta usamodzielnione w wyniku secesji,

O) dawne osiedla miejskie, N) zupełnie nowe miasta

Kolejna grupa miast ustanowionych w latach 19802011 to ośrodki powstałe w strefach ekspansji aglomeracji miejskich. W porównaniu ze strefami dyfuzyjnymi proces umiastowienia charakteryzował się tam wy- raźnymi opóźnieniami w przyznawaniu praw miejskich (Krzysztofik 2006). Opóźnienia te wynikają m.in. z tzw. cienia większych miast (Krzysztofik 2006) oraz z małego zainteresowania społeczności lokalnych uzys- 


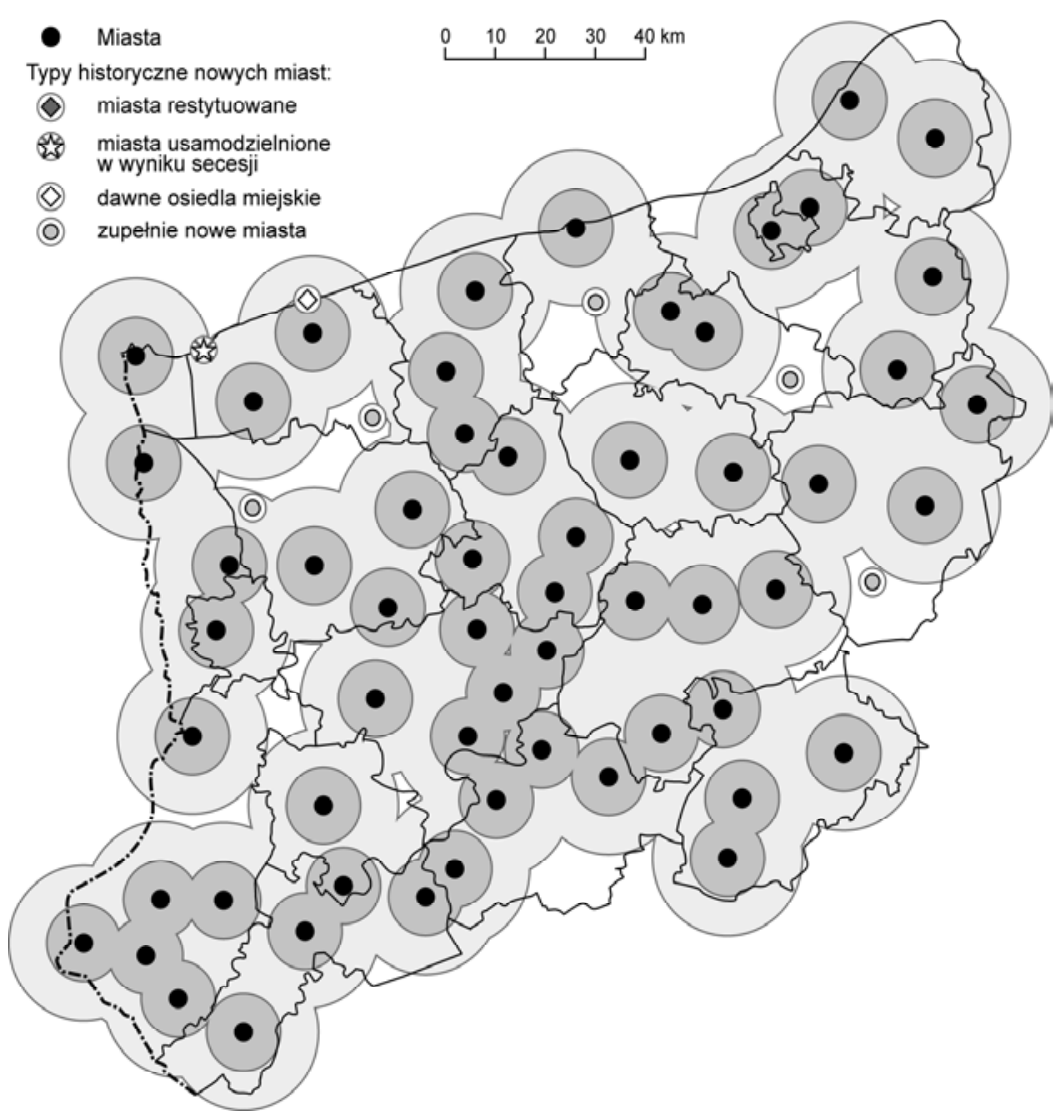

Rys. 7. Nowe miasta w regionie zachodniopomorskim na tle stref buforowych (o promieniach 1 i 2 mili) wokół miast istniejących w $1978 \mathrm{r}$.

kaniem praw miejskich dla swojej miejscowości (Drobek 2002, Staszewska 2005/6). W siedmiu strefach aglomeracyjnych (tab. 3) powstało w sumie tylko 15 miast (z czego 40,0\% stanowią miasta zupełnie nowe), mimo że $\mathrm{w}$ otoczeniu dużych miast znajduje się wiele wsi znacznych pod względem liczby ludności i silnie zurbanizowanych, mogących starać się o formalne uznanie ich miejskości.

Ostatnim modelem zaobserwowanym w procesie rozwoju liczby miast w latach 1978-2016 było powstawanie miast w „strefach bezmiejskich”, za które uznano obszary położone $\mathrm{w}$ pewnym oddaleniu ${ }^{3}$ od miast istniejących, gdzie ze względu na niedobór miast w sieci osadniczej określone funkcje miejskie musiały przejąć duże wsie (rys. 6). Miejscowości te zwykle stanowią siedziby gmin wiejskich i są lokalnymi ośrodkami centralnymi, pełniąc funkcje obsługi dla swojego (często rozległego) zaplecza. Na terenie Polski wyróżniono jedną „strefę bezmiejską" - strefę zachodniopomorską (rys. 7), w której zostały już zapoczątkowane procesy umiastowienia. W latach 1978-2016 prawa miejskie w tym regionie otrzymało siedem miejscowości: Międzyzdroje (1984), Golczewo (1990), Borne Sulinowo (1993), Dziwnów (2004), Tychowo (2010), Gościno (2011) i Stepnica (2014), z czego pięć (Golczewo, Borne Sulinowo, Tychowo, Gościno i Stepnica) jako miasta zupełnie nowe. Pozostałe dwa miasta miały z kolei krótkie tradycje miejskie: Międzyzdroje były miastem w latach 1945-1973 (a następnie stanowily część miasta Świnoujście), a Dziwnów w latach 19581972 posiadał status osiedla miejskiego.

\section{MECHANIZM POWSTAWANIA MIAST W „STREFACH BEZMIEJSKICH”}

W opracowaniu przyjmujemy, że geneza danego miasta jest ściśle związana $\mathrm{z}$ funkcjami, jakie pełni ono w relacji do szeroko pojętego otoczenia. Tym samym zwracamy uwagę na egzocentryczny charakter miasta w momencie jego prawnoadministracyjnego ukonstytuowania się. Ten funkcjonalistyczny punkt widzenia ma jednak nadrzędną płaszczyznę wyjaśnień, którą określamy w tym miejscu jako ontologiczną. Doprecyzowując, przyjmujemy mechanicystyczno-termodynamiczny model wyjaśnień, który opiera się na założeniu, że urbanizacja jest efektem oddziaływania pierwotnych sił dośrodkowych i (lub) odśrodkowych, które kształtują przestrzeń antropogeograficzną przy współudziale zjawiska dyfuzji innowacji lub idei. R. Krzysztofik (2014) przyjął, że za rozwój egzogenicznych funkcji wyspecjalizowanych (wg koncepcji bazy 
ekonomicznej) odpowiedzialne są siły odśrodkowe. Siły dośrodkowe nawiązują natomiast do pojęcia funkcji centralnych, rozpatrywanych zarówno z perspektywy koncepcji bazy ekonomicznej, jak i teorii ośrodków centralnych. Z uwagi na specyfikę organizacji przestrzeni społeczno-ekonomicznej genetyczny może być tylko jeden z wymienionych typów sił miastotwórczych (Krzysztofik 2014). Natomiast na etapie późniejszego rozwoju rola poszczególnych sił jako stabilizatora ekonomicznego bytu miasta może być z jednej strony wyrównana, z innej zaś może się całkowicie zmieniać (Krugman 1995, Krzysztofik 2014).

W okresie powojennym (tzw. socjalistycznym) do 1989 r. w genezie nowych miast Polski zdecydowanie przeważały siły odśrodkowe i wywoływane ich oddziaływaniami funkcje wyspecjalizowane (Krzysztofik 2014). Współcześnie (po 1989 r.), w efekcie serwicyzyzacji gospodarki, wzrostu roli administracji lokalnej jako pracodawcy, a także na skutek kryzysu niektórych branż przemysłu rola funkcji wyspecjalizowanych zdecydowanie zmalała. Daje to zatem asumpt do zastanowienia się, jaka jest rola poszczególnych sił w powstawaniu nowych miast, a w tym przypadku miast w zdefiniowanych „strefach bezmiejskich”. Z poprzedniego rozdziału wiemy, że w niektórych spośród z nich istnieje silny potencjał rozwoju dyfuzji idei umiastowienia. Jednak warto jest przyjrzeć się, jakie siły odpowiadają za gospodarcze tło urbanizacji jednostek osadniczych starających się o przyznanie statusu miasta.

Generalnie można wyodrębnić dwa modele (rys. 8). Pierwszym jest typ przemian miejscowości rolniczej (z wyspecjalizowanymi funkcjami egzogenicznymi), w której z uwagi na relatywnie duży potencjał demograficzny następuje silny przyrost instytucji ekonomiczno-społecznych o funkcjach centralnych. Stopniowo dochodzi wtedy do wypierania funkcji rolniczych (wyspecjalizowanych) i równoważenia ich funkcjami centralnymi. Działaniom tym w sposób szczególny sprzyja właśnie „bezmiejskość” otoczenia. Miejscowość taka wzmacnia przewagę konkurencyjną nie tylko nad sąsiednimi mniejszymi jednostkami osadniczymi, lecz jest zdolna także (w odniesieniu do niektórych usług) konkurować z większymi ośrodkami zlokalizowanymi w znacznej odległości. Dotyczy to także miast szczebla powiatowego. Oczywiście powodem tej przewagi są relatywnie duże odległości pomiędzy rozpatrywanym ośrodkiem a jednostkami już umiastowionymi. Uwzględniając fakt, iż część z nich pod względem potencjału demograficznego oraz poziomu rozwoju usług i handlu nie przewyższa zbytnio takiego ośrodka, automatycznie zyskują one istotną rolę w organizacji społeczno-ekonomicznej na poziomie lokalnym. Rosnące znaczenie funkcji centralnych takiego ośrodka w naturalny sposób stanowi też stymulantę napływu całkiem nowych funkcji wyspecjalizowanych, z reguły przemysłu. Miejscowość taka wchodzi wtedy w fazę równoważenia funkcji. Trudno jest wtedy ocenić rzeczywistą przewagę znaczenia każdej z funkcji dla danego roku, co wynika z faktu, iż rozwój nowych funkcji wyspecjalizowanych powoduje zdynamizowanie rozwoju funkcji centralnych. Ten model rozwoju odnieść można do Golczewa i Gościna, w grupie jednostek osadniczych już umiastowionych w województwie zachodniopomorskim, czy Sierakowic (woj. pomorskiej) i Osieka (woj. kujawsko-pomorskie) w grupie miast potencjalnych.

Drugi model nawiązuje do pogłębiania się funkcji wyspecjalizowanych w ośrodkach, które już takie funkcje pełnią. W tym przypadku oddziałują siły odśrodkowe, a specyficzna lokalizacja lub występowanie dobra miastotwórczego powoduje dalszą kumulację potencjału miastotwórczego opartego na relacjach odśrodkowych. Najczęściej oddziaływanie tych sił nawiązuje do funkcji przemysłowej i turystyczno-wypoczynkowej, przy czym można wyróżnić tu dwie ścieżki ewolucji. W pierwszej z nich miejscowość taka uzyskuje np. funkcje przemysłowe w wyniku zastąpienia nimi dotychczasowych funkcji rolniczych (np. Czarna

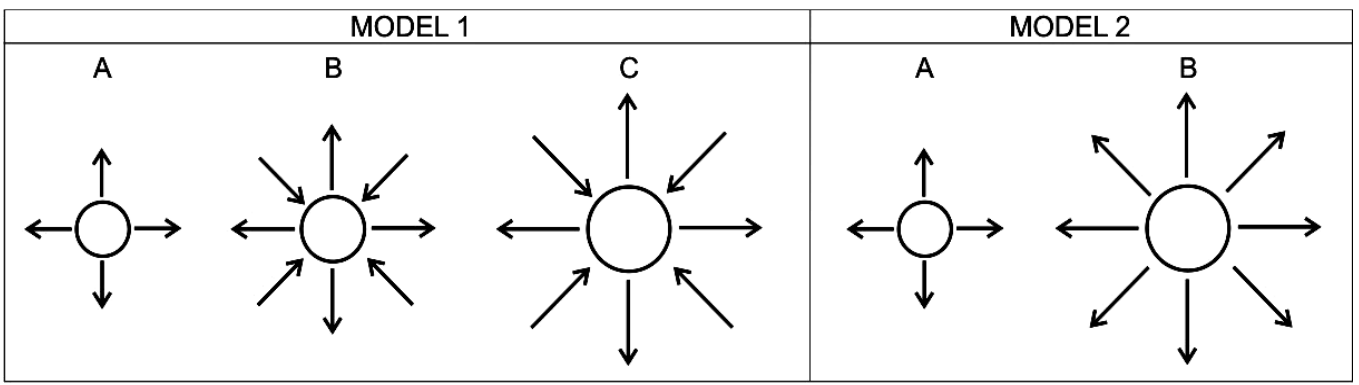

Rys. 8. Mechanizmy powstawania miast w „strefach bezmiejskich” (objaśnienia w tekście) 
Woda). W drugiej zaś jednostka taka powstała jako przemysłowa in cruda radice, a po jakimś czasie, w efekcie przewagi konkurencyjnej $\mathrm{w}$ regionie, funkcja ta zostaje wzmocniona kolejnymi zakładami przemysłowymi. Ta droga rozwoju była charakterystyczna np. dla Dziwnowa. Oba te modele, z wyraźną ekspozycją funkcji wyspecjalizowanych stymulowanych siłami odśrodkowymi, odgrywają współcześnie rolę zbliżoną do tej, w której siły dośrodkowa i odśrodkowa równoważą się.

\section{MIASTA POTENCJALNE W „STREFACH BEZMIEJSKICH”}

Analiza rozmieszczenia miast na terenie Polski (rys. 9) umożliwiła identyfikację kilku „stref bezmiejskich”, w których w oddaleniu od istniejących ośrodków miejskich funkcjonują duże wsie bez tradycji miejskich, pełniące funkcje centralne. Ośrodki te, z uwagi na wysoki stopień zurbanizowania, znaczną liczbę ludności i rozległe zaplecze, w obliczu podjęcia starań o formalne uznanie miejskości, mają bardzo realne szanse na uzyskanie statusu miasta. Można je zatem traktować jako potencjalne nowe miasta. Wśród zidentyfikowanych na terenie kraju „stref bezmiejskich” procesy umiastowienia najbardziej prawdopodobne wydają się w przypadku:

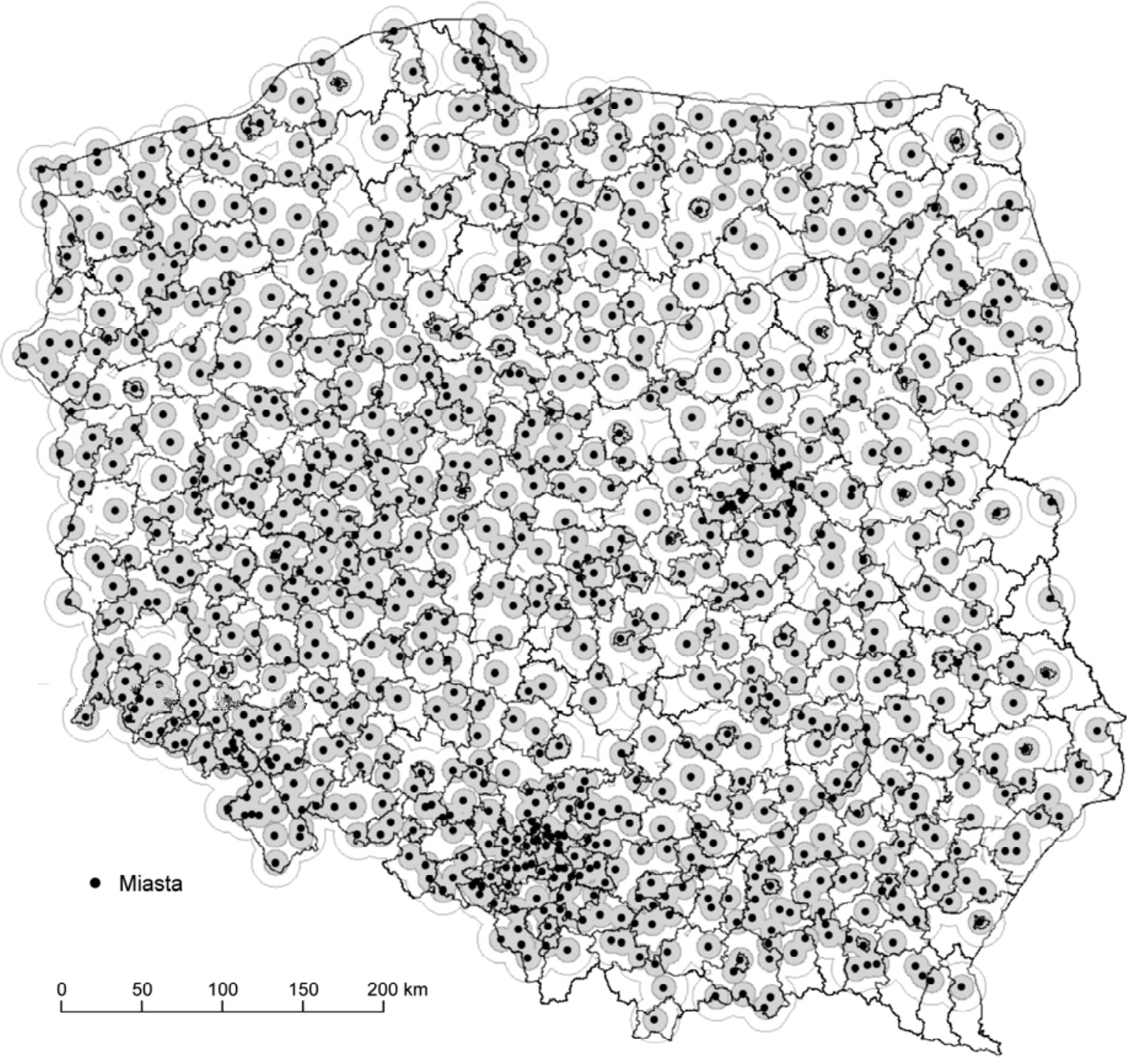

Rys. 9. Strefy buforowe (o promieniach 1 i 2 mili) wokół miast istniejących w 2016 r. 


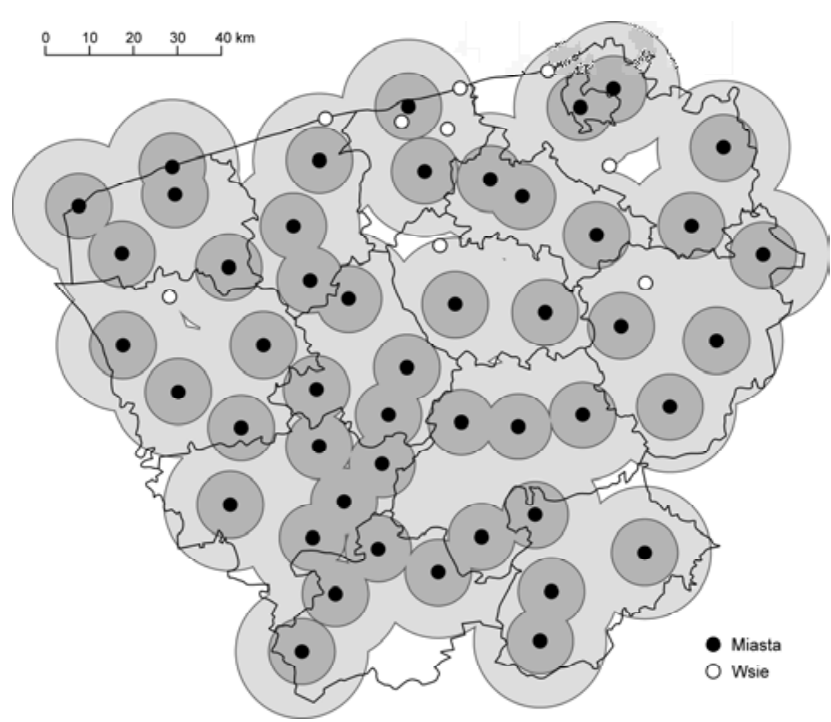

Rys. 10. Duże wsie w środkowo-wschodniej części województwa zachodniopomorskiego na tle stref buforowych (o promieniach 1 i 2 mili) wokół miast

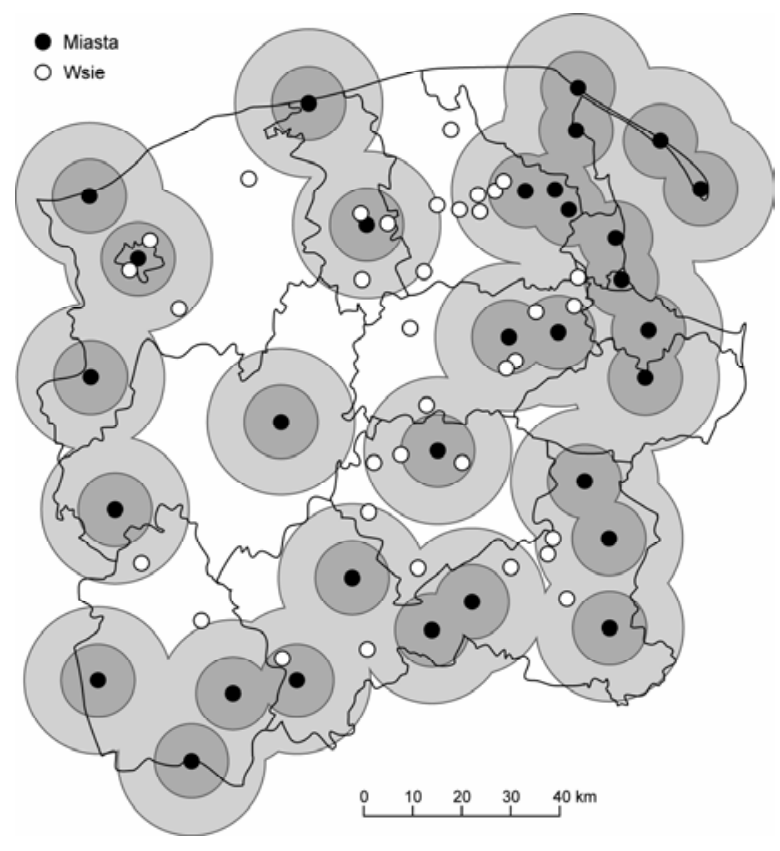

Rys. 11. Duże wsie w środkowo-zachodniej części województwa pomorskiego na tle stref buforowych (o promieniach 1 i 2 mili) wokół miast

1) północno-wschodniej części województwa zachodniopomorskiego (rys. 10), gdzie procesy umiastowienia w odniesieniu do dużych wsi położonych w „strefach bezmiejskich” zostały zapoczątkowane już w latach 90. XX w. - największe szanse na uzyskanie statusu miasta $\mathrm{w}$ tym regionie mają Mielno w powiecie koszalińskim (3239 mieszkańców ${ }^{4}$ ), które już złożyło odpowiednie wnioski do Ministerstwa Spraw Wewnętrznych ${ }^{5}$, i Ustronie Morskie (2417) w powiecie kołobrzeskim;

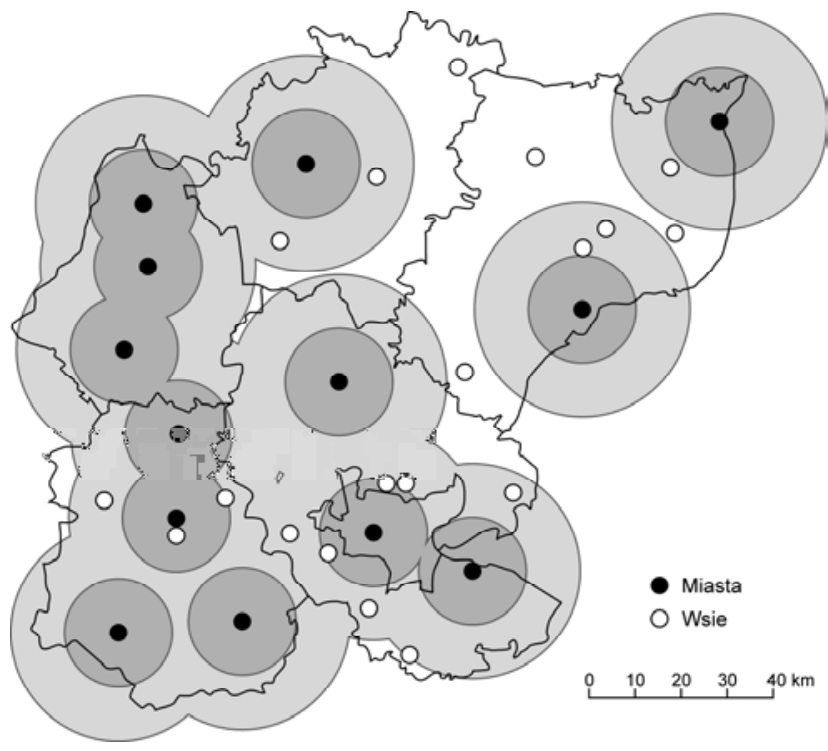

Rys. 12. Duże wsie w północnej części województwa kujawsko-pomorskiego na tle stref buforowych (o promieniach 1 i 2 mili) wokół miast

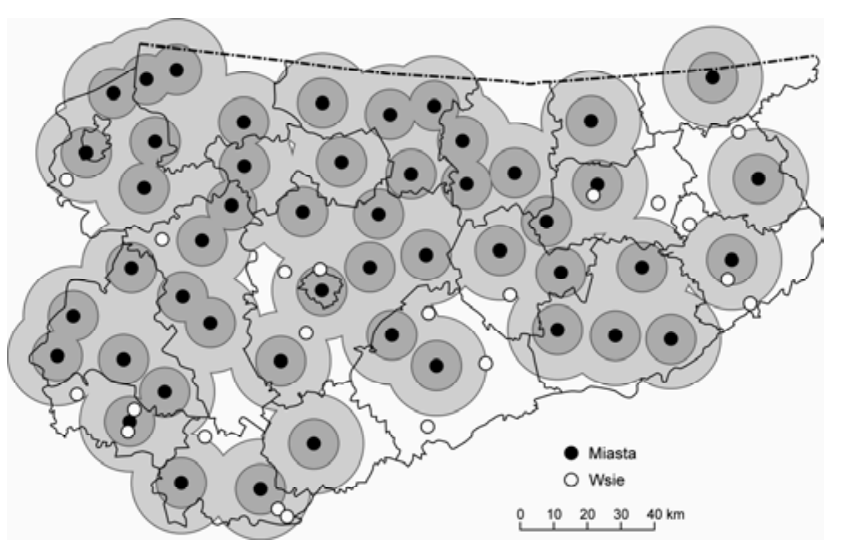

Rys. 13. Duże wsie w województwie warmińsko-mazurskim na tle stref buforowych (o promieniach 1 i 2 mili) wokół miast

2) środkowo-zachodniej części województwa pomorskiego (rys. 11) - w tym regionie duże wsie występują zarówno w sąsiedztwie głównych ośrodków miejskich (tzn. aglomeracji trójmiejskiej i Słupska), jak i w oddaleniu od istniejących miast - spośród nich największe szanse na umiastowienie mają: Sierakowice (7373 mieszkańców) w powiecie kartuskim, Luzino (7264) w powiecie wejherowskim, Dębnica Kaszubska (3805) i Kobylnica (2883) w powiecie słupskim, Zblewo (3435) w powiecie starogardzkim, Przechlewo (2862) w powiecie człuchowskim i Lipusz (2611) w powiecie kościerskim;

3) północnej części województwa kujawsko-pomorskiego (rys. 12) - największe wsie leżące w oddaleniu od istniejących miast $\mathrm{w}$ tym regionie to: 
Osie (2815 mieszkańców), Pruszcz (2666) i Laskowice (2572) w powiecie świeckim oraz Śliwice (2464) i Gostycyn (2441) w powiecie tucholskim;

4) wschodniej i południowej części województwa warmińsko-mazurskiego (rys. 13) - gdzie największe szanse na uzyskanie statusu miasta mają: Iłowo-Osada (2989 mieszkańców) i Rybno (2621) w powiecie działdowskim, Prostki (3029) w powiecie ełckim, Piecki (3341) w powiecie mrągowskim, Wydminy (2367) w powiecie giżyckim i Kowale Oleckie (2068) w powiecie oleckim, a także byłe miasta: Kurzętnik (3142) w powiecie nowomiejskim i Wielbark (2911) w powiecie szczycieńskim.

\section{PODSUMOWANIE I WNIOSKI}

Powstawanie miast w Polsce jest współcześnie procesem wykazującym dość dużą dynamikę. Wśród tego licznego zbioru nowych miast szczególną funkcję pełnią ośrodki powstające $\mathrm{w}$ tzw. strefach bezmiejskich. Umiastowienie tych miejscowości jest ułatwione o tyle, że mają one na poziomie lokalnym dość wyraźną przewagę konkurencyjną w stosunku do jednostek osadniczych, w których sieć miejska jest już dość gęsta. W artykule wykazano, że ośrodki takie mogą rozwijać się zarówno w oparciu o miastotwórcze siły dośrodkowe, jak i odśrodkowe. Przypominając - pierwsze z nich odpowiadają za rozwój funkcji centralnych, drugie zaś - wyspecjalizowanych, przy czym (paradoksalnie) dość istotną rolę w „strefach bezmiejskich” odgrywają te drugie. W części spośród umiastowionych miejscowości jest to naturalna kontynuacja rozwoju wcześniejszych funkcji, a w innych funkcje wyspecjalizowane równoważą funkcje centralne.

$\mathrm{Z}$ ontologicznego punktu widzenia, a nawiązującego do ujęcia termodynamicznego, zwrócono uwagę na to, że w Polsce dyfuzja idei miejskości (uzyskiwania statusu miasta) przyjmuje trzy zasadnicze modele. Jednym z ważniejszych (zwłaszcza w Polsce północnej i wschodniej) jest dyfuzja miast w strefach bezmiejskich. Oczywiście zjawisko ma tu swoje skończone możliwości, wynikające z rosnącego zagęszczenia sieci miast w dotychczasowej „strefie bezmiejskiej”. W północnej części Polski z uwagi na tę cechę sieci osadniczej należy oczekiwać dalszego zaawansowania omawianych $\mathrm{w}$ tej pracy procesów, a któremu sprzyjać powinien lokalny wzrost gospodarczy oraz wzrastające poczucie samorządności i aktywności społecznej.

\section{PRZYPISY}

${ }^{1}$ Wyłączając miasta przywrócone w wyniku secesji średnia liczba ludności miast ustanowionych w latach 1978-2016 w roku nadania im praw miejskich wyniosłaby około 2940 osób, a największymi miastami w tym zbiorze byłyby Jelcz-Laskowice (12 059 mieszkańców w 1987 r.) i Łomianki (11 005 w 1989 r.).

2 Przyjęto, że strefy dyfuzji idei umiastowienia powinny stanowić zgrupowania co najmniej czterech nowych miast położonych w kilku sąsiednich powiatach, a zgrupowania obejmujące dwa lub trzy nowe miasta uznano jako tzw. dyfuzyjne układy zalążkowe.

${ }^{3}$ Obszar bezmiejski został wyznaczony w oparciu o prawo jednej mili (ok. $8 \mathrm{~km}$ ) stosowane w średniowieczu do wyznaczenia zasięgu oddziaływania handlowego miasta.

${ }^{4}$ Liczba ludności potencjalnych nowych miast na podstawie danych NSP 2011.

51 stycznia 2017 r. Mielno uzyskało status miasta.

\section{BIBLIOGRAFIA}

Drobek W., 1999, Rola miast zdegradowanych w sieci osadniczej Śląska, Wyd. Instytut Śląski w Opolu, Opole.

Drobek W., 2002, Polskie nowe miasta (1977-2001), [w:] J. Słodczyk (red.), Przemiany bazy ekonomicznej i struktury przestrzennej miasta, Wyd. Uniwersytetu Opolskiego, Opole, s. 71-84.

Dymitrow M., 2012, The Hidden Face of Urbanity. Morphological Differentiation of degraded and Restituted Towns in Poland in the Context of Efficiency of National Administrative System, University of Gothenburg: Department of Human and Economic Geography and Department of Earth Sciences, Gothenburg.

Jarczewski W., 2002, Odzyskana niezależność. Przyczyny i skutki powstania nowych gmin na obrzeżach GOP ${ }_{w}$ latach 90., Wydawnictwo Dante, Kraków.

Krugman P., 1995, Urban Concentration: The Role of Increasing Returns and Transport Costs, [w:] Proceedings of The World Bank Annual Conference on Development Economics (1994), The International Bank for Reconstruction and Development, The World Bank, s. 241-263.

Krzysztofik R., 2006, Nowe miasta w Polsce w latach 1980-2007. Geneza i mechanizmy rozwoju. Próba typologii, Uniwersytet Śląski, Sosnowiec.

Krzysztofik R., 2007, Lokacje miejskie na obszarze Polski. Dokumentacja geograficzno-historyczna, Wyd. Uniwersytetu Śląskiego, Katowice.

Krzysztofik R., 2012, Umiastowienie obszaru Polski. Interpretacja geograficzno-historyczna, Wyd. Naukowe „Śląsk”, Katowice.

Krzysztofik R., 2014, Geneza aglomeracji miast na obszarze Polski, Wyd. Uniwersytetu Śląskiego, Katowice.

Lisowska A., Szmytkie R., 2014, Definicja miasta i kryteria miejskości w prawie polskim, [w:] K. Kuć-Czajkowska, M. Sidor (red.), Miasta, aglomeracje, metropolie $w$ nurcie globalnych przemian, Uniwersytet Marii Curie-Skłodowskiej, Lublin, s. 17-31.

Łoboda J., 1983, Rozwój koncepcji i modeli przestrzennej dyfuzji innowacji, Studia Geograficzne”, 37, „Acta Universitatis Wratislaviensis", 585.

Najgrakowski M., 2009, Miasta Polski do początku XXI wieku, „Dokumentacja Geograficzna", 39, IGiPZ PAN, Warszawa.

Powierzchnia i ludność w przekroju terytorialnym, 1994-2015, 2016, Informacje i opracowania statystyczne, GUS, Warszawa. 
Sokołowski D., 2008. Miasta nowe i potencjalne jako główne elementy kontinuum wiejsko-miejskiego w Polsce, [w:] A. Jezierska-Thöle, L. Kozłowski (red.), Gospodarka przestrzenna w strefie kontinuum miejsko-wiejskiego, Wyd. Naukowe UMK, Toruń, s. 63-78.

Staszewska S., 2005/6, Miasto czy wieś. Uwarunkowania rozwoju i zagospodarowanie podmiejskich jednostek osadniczych (przykład Kozichgłów), [w:] K. Heffner, T. Marszał (red.), Małe miasta. Studium przypadków, Wyd. Uniwersytetu Łódzkiego, Łódź, s. 61-73.

Szmytkie R., 2003, Znaczenie osiedli miejskich w kształtowaniu systemu osadniczego Polski w okresie powojennym, „Czasopismo Geograficzne", 74 (1-2), s. 59-77.

Szmytkie R., 2005, Dezintegracja miast-zlepieńców, [w:] I. Jażdżewska I. (red.), Współczesne procesy urbanizacji $i$ ich skutki, XVIII „Konwersatorium Wiedzy o Mieście”, Wyd. Uniwersytetu Łódzkiego, Łódź, s. 379-387.
Szmytkie R., 2012, Zmiany liczby miast $w$ Polsce w okresie powojennym, [w:] S. Ciok, S. Dołzbłasz (red.), Problemy wspótpracy transgranicznej i kształtowania ponadkrajowych powiązań gospodarczych, Rozprawy Naukowe Instytutu Geografii i Rozwoju Regionalnego, 28, Uniwersytet Wrocławski, Wrocław, s. 155-171.

Szmytkie R., 2014, Procesy inkorporacji i secesji miast w Polsce po 1945 r., [w:] K. Kuć-Czajkowska, M. Sidor (red.), Miasta, aglomeracje, metropolie $w$ nurcie globalnych przemian, Uniwersytet Marii Curie-Skłodowskiej, Lublin, s. 177-200.

Szmytkie R., Krzysztofik R., 2011, Idea miejskości w Polsce, [w:] B. Namyślak (red.), Przekształcenia regionalnych struktur funkcjonalno-przestrzennych, t. 2: Zmiany funkcjonalno-przestrzenne miast $i$ obszarów wiejskich, Rozprawy Naukowe Instytutu Geografii i Rozwoju Regionalnego, 20, Uniwersytet Wrocławski, Wrocław, s. 25-39.

Zmiany administracyjne miast 1945-1984, 1985, „Statystyka Polski. Statystyka Regionalna", 7, GUS, Warszawa. 